\title{
Mongolian Buddhist Scholars' Works on Infectious Diseases (Late 17th Century to the Beginning of the 20th Century)
}

\author{
Batsaikhan Norov \\ Independent Researcher, Oxford OX51DQ, UK; bsaikhan4@gmail.com \\ Received: 15 February 2019; Accepted: 23 March 2019; Published: 27 March 2019
}

\begin{abstract}
The Qing period saw both the flowering of Buddhism in Mongolia as well as the arrival of new infectious diseases such as smallpox and syphilis which had reached epidemic levels by the 17th to early 20th centuries. During that critical period, a considerable number of Mongolian Buddhist scholars produced a substantial amount of works dedicated to the ways of fighting epidemics. This paper explores the efforts of Mongolian Buddhist scholars in countering this new threat, within the unique social and political milieu of the time. Smallpox spread severely reduced the Mongolian population and could have influenced the change of political control in the region, as several prominent Mongolian leaders who fought against Qing domination were themselves victims of smallpox epidemics. Similarly, at the beginning of the 20th century, around half the Mongolian population was infected by syphilis and, as a result, the population further declined in numbers. Tibetan Buddhist medicine, which was introduced to Mongolia from Tibet, was enriched by Mongolian traditional medical practices and fused with traditional Mongolian and Chinese medical knowledge during Mongolian scholars' search for preventive methods against infectious diseases. This article examines the works of three renowned Mongolian Buddhist scholars who dealt with issues of infectious diseases: Ye shes dpal 'byor, Chakhar Géshé Lobsang Tsültim, and Lobsang chos 'phel.
\end{abstract}

Keywords: smallpox; syphilis; plague; infectious disease; Mongolian Traditional Buddhist Medicine; Qing Dynasty; Chakhar Géshé Lobsang Tsültim; Ye shes dpal ‘byor; Lobsang chos 'phel

\section{Introduction}

Seventeenth century Mongolia, a land of pastoral nomads with a semi-arid environment and unpredictable weather conditions, experienced warfare as well as a severe outbreak of infectious diseases such as smallpox and syphilis within its population. According to Peter C. Perdue, after the collapse of the Yuan Dynasty in 1368 Mongols were almost isolated from the European and Asian urban epicenters of many pathogens (Perdue 2005, p. 47). As a consequence, a vulnerable new generation grew up without exposure to a number of deadly diseases, which led to the lack of immunity. As the Qing Dynasty (1644-1911) expanded, new contagious diseases were spread among the indigenous population by the Qing soldiers and Chinese traders (Pozdneyev 1980; Pozdneyev 1971; Andrews 1921). When Mongolian native inhabitants encountered these diseases, the results were fatal for the population, causing its drastic decrease.

During the period of Buddhist flourishing in Mongolia from the 17th to the early 20th centuries, opportunities arose for the adoption and development of new medical theories and practices performed by specially trained monks who were based in hundreds of Buddhist monasteries in Mongolia. They offered medical services that replaced the former shamanic healing practices. Many Mongolian monks 
studied Tibetan Buddhist medicine and wrote their medical works primarily in the Tibetan language. ${ }^{1}$ In addition, they translated a significant number of medical texts into the Mongolian language, as well as producing some works in Mongolian. Many of these works have been studied in modern times, but are largely unknown outside Mongolia, Inner Mongolia and Buryatia as they have not been published in English.

The fundamental text of Tibetan medicine, the Four Medical Tantras, was first translated into Mongolian in the 14th century (Ochir and Enkhtuvshin 2004, p. 285). However, from the 16th century onwards, efforts to translate Tibetan texts into Mongolian accelerated significantly and the most important Tibetan medical treatises were published in Mongolian. This resource became a springboard for Mongolian scholars to develop their own knowledge and practice. Furthermore, a considerable number of Mongolian scholars produced a large number of original medical treatises on medical theory, medicinal plants, raw materials and medical treatments. The most significant of these relating to infectious diseases were written by Sumpa mkhanpo Ye shes dpal 'byor (1704-1788), Chakhar Géshé Lobsang Tsültim (1740-1810) and Lobsang chos 'phel (19th century). Their works contain sections dedicated directly to the prevention and treatment of infectious diseases.

For the purpose of identifying the situation of infectious diseases in Mongolia during the 17th to the early 20th centuries, four of the most influential medical treasures written by Buddhist scholars from different regions of Mongolian territories are presented in this article. The relevant works written by Sumpa mkhanpo Ye shes dpal 'byor, ethnically an Oirat Mongol, born in Kokonor (Hanung 2014)

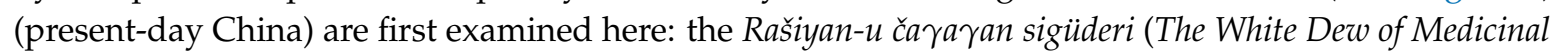
Elixir) and the Rašiyan-u dusul (Drop of Medicinal Elixir). Among his medical works, the most famous are the four texts collectively known as the Durben Rašiyan (Four Medicinal Elixirs), which include the two above mentioned works. Sumpa mkhanpo Ye shes dpal 'byor wrote the Rašiyan-u undurul (The Spring of Medicinal Elixir) in 1751, the Rašiyan-u čararan sigüderi (The White Dew of Medicinal Elixir) in 1752, the Rašiyan-u dusul (Drop of Medicinal Elixir) in 1759, while the Rašiyan-u qurim (The Assembles of Medicinal Elixir) was written in 1785 when he was 81 years old. According to De Jong "Sum-pa mkhan-po was one of the outstanding scholars of the Lamaist world" (De Jong 1967), and well known for integrating certain pre-Buddhist, Mongolian traditional healing methods with Buddhist medicine (Atwood 2004, p. 345).

The third text discussed here is titled ' $\mathrm{Ba}$ ' sam sman mar dang 'dud rtsi lnga lum sogs bya tshul (The Method to Prepare Oil based Basam Medicine and Five Elixir Medicinal Baths), which is contained in the sixth volume of the "Collected Works" 2 of Chakhar Géshé Lobsang Tsültim (1740-1810). Lobsang Tsültim, who was from Chakhar district (Mong. khoshuu) in Inner Mongolia (present-day China), wrote works on various Buddhist subjects including medicine. His biography and some other works were intensively studied in Mongolia and Inner Mongolia. In the colophon to the above mentioned work, he clarified his purpose for writing it in this way: "There are many methods of treatment about which physicians mostly do not know, or if they do know, they do not tell it to others. I wrote this for the kind hearted people."

Lastly, the fourth text under our study is Gces bsdus snying nor (Precious Collections of Selected Texts) (publication date unknown). It was created by Lobsang chos 'phel (19th century), who was born in Dalai wang-yin district in the province of Tsetsen Khan (now Sukhbaatar Province of Mongolia) (Sharav 2006). Lobsang chos 'phel based this work on the most advanced ideas presented in the previously available medical treatises, including the works of Ye shes dpal 'byor and Lobsang Tsültim. As the mentioned medical treatises were published in the course of the 18th to 19th centuries, they

1 According to Evelyn S. R. (2005), $16.9 \%$ of the works produced by Mongols during the Qing dynasty were found to be in foreign languages, of which $61 \%$ were related to Tibetan Buddhism.

2 His "Collected Works" were printed in 1802 (vols. 1-7), 1807 (vol. 8), and 1809 (vols. 9, 10) in the White Mount Temple, Inner Mongolia. 
serve as a valuable source of information regarding the development of Mongols' knowledge of infectious disease by that time.

Some research studies are available about the above mentioned scholars' lives and works but unfortunately little about their medicine related treatises. Studies about Sumpa mkhanpo and Chakhar Géshé began to appear in Mongolia from the late 1950s by scholars such as Bira Sh., (Bira 1960); Damdinsuren Ts., (Damdinsuren 1958, 1975); and Altangerel Ch., (Altangerel 1967). According to Ochi (1996), until the 1980s not many studies were produced about Chakhar Géshé in Inner Mongolia; however, they increased after that time (Ochi 1996). On the other hand, studies related to Lobsang chos 'phel and his works are still somewhat of a rarity. Nonetheless Khaidav Ts. concluded that Lobsang chos 'phel's work is one of the most interesting manuals among the other Mongolian scholars' works (Khaidav 1975). Whereas Sühe (2002) states Gces bsdus snying nor by Lobsang chos 'phel includes several diseases and treatment methods which are not described in the Four Medical Tantras (Sühe 2002).

\section{Brief Historical Background}

The development of Buddhism among Mongols flourished during the period of control by the Manchu Qing Dynasty. Early relations between the Manchu and Mongols led to peace treaties in the 1620s (Cosmo 2012). In the beginning, the Manchu adopted the Mongolian traditional practices and the Uighur-Mongolian script around the 1600s (Sinor 1997). For political reasons that would keep Mongols under their power (Bayarsaikhan 2004) and in order to strengthen the Qing influence in Mongolia (Ochir and Enkhtuvshin 2004), the Qing emperors like Kangxi (r. 1662-1722), Yongzheng (r. 1723-1735) and Qianlong (r. 1736-1796) supported Buddhist development in Mongolia. For this reason, during the 17th and 18th centuries, Mongolian monasteries and medical facilities (Elverskog 2006) enjoyed their most active period of development. The first medical college in Mongolia was established in 1685 (Baigalma 2006), and was followed by many Buddhist medical colleges that trained a large number of physicians.

During the Qing period, Mongols suffered greatly from widespread epidemics of infectious diseases which resulted in a considerable decrease in the Mongolian population and reduced life expectancy. Here we discuss some of the infections which had a major impact.

\subsection{Smallpox}

Northern nomads, including Mongols and Manchus, were exposed to smallpox infection from their southern neighbors across the Great Wall. According to Henry Serruys, we know from sources dating to the Ming Dynasty (1368-1644) that smallpox did spread among Mongolian nomads. Nevertheless, the spread of infection was rare among nomads in comparison to the spread among Chinese residents (Serruys 1980). The main cause of Mongols' contact with Chinese settlers in that area was border trade and a border conflict, both of which proved to be deadly for the Mongolian population. Likewise, the public's inadequate understanding of epidemiology and poor hygiene contributed to the spread of smallpox, which resulted in a high death rate among the more vulnerable members of society (Cariceo 1994). A series of smallpox epidemics and droughts had already taken place during the mid-16th century in Mongolia (Atwood 2004). Unfortunately, the political conditions of that time did not allow the Mongols to take effective action against the disease. It is reported that in 1630, the Mongols attacked China with an army that consisted of only immunized soldiers (Hays 2005). Meanwhile, the Qing took many preventive measures against the disease, such as setting up a smallpox investigation unit in 1622, which continued for the next two centuries (Chang 2002). Emperor Kangxi started inoculation for the royal family in 1687 , and eventually his successors made it obligatory for all Manchu children. This may have been the first ever compulsory communal immunization for children in human history. Due to severe smallpox epidemics among the Mongol population, Qing authorities sent inoculators to Mongol children who were living around the Manchu armed base camp in Ordos (Perdue 2005). 
One tragic result of these epidemics among the Mongols was that one third of the Oirat population, including the Khan Galdantseren, died of smallpox in 1745 (Perdue 2005). The smallpox epidemics were an influential factor in the resolution of the conflict between the Oirat and the Qing. When another wave of epidemic spread throughout Khalkha and Oirat territories, half the Oirat population was wiped out, and most of the other half was killed by the Qing army in the course of three years of war, from 1756 to 1758 . Likewise, the epidemic had a terrible impact on Khalkha populations, killing among others the Second Jebtsundamba Khutugtu (1724-1758) (Bareja-Starzyńska 2018), the head of Mongolian Buddhism at that time. According to Atwood (2004), the Second Jebtsundamba Khutugtu was inoculated against smallpox in 1730 in preparation for his visit to Beijing. If this was the case, his death from smallpox becomes questionable, especially in the light of rumors at that time that he was poisoned due to supporting the rebellion against the Qing in 1756-1758. Later the Sixth Jebtsundamba (1843-1848) died of smallpox in 1848, soon after he was brought from Tibet to Khalkha (Bareja-Starzyńska 2018).

Overall, many other leaders who fought against the Qing authority died from smallpox and other infections. To name a few, they include Ligden Khan in 1644 (Hopkins 2002), Galdan Boshigtu in 1697 (Parker 1907), Amursana in 1758 (Atwood 2004), and many others. The loss of large numbers of the Mongolian population weakened the country's capacity for self-defence, and it destabilized Mongolia's self-governance.

At the beginning of the 20th century, social conditions were still perilous; therefore a limited study of only 60 families living near the Gandantegchenling Monastery in Urga (present Ulaanbaatar) was carried out in 1914. It showed that half the children in those families died of smallpox (Rupen 1964, p. 349). Due to the wide spread of smallpox epidemics in Mongolia, the Qing authorities prohibited Mongolian aristocrats and their families who had not had the disease from visiting Beijing. Those who were receiving their titles of nobility were only allowed to visit Je-ho city, north of the Great Wall, instead of arriving in Beijing (Edict, 1784, quoted by Serruys 1980).

\subsection{Syphilis}

Syphilis was a new infectious disease which had another very profound impact on the Mongolian population, as almost half the population was infected by the early 20th century. In the beginning of the 20th century, $42 \%$ of the population was infected by syphilis in Buriat Mongolia, now modern-day Russia (Solomon 1993). The conditions in Khalkha Mongolia were no better, as almost the entire population was infected with venereal diseases by this time (Bawden 1968). By the mid-20th century, more than half the population in Inner Mongolia was infected with syphilis (Ochirbat 1974; Bulag 2010). Sexually transmitted diseases were one of the major factors in early death among Mongols of that time, and had fatal consequences for fetuses. All this nearly destroyed the entire Mongolian population.

There is no exact evidence when syphilis first came to Mongolia. The Mongolian scholar Dolgor (Dolgor and Nyamdorj 1960) discovered in the Mongolian National Archives that the first documentation of the syphilis infection in Chakhar territory occurred in $1785 .^{3}$ Coincidently, the disease was recognized at Lobsang Tsültim's place of residence in the same Chakhar territory at same time when he was writing about a treatment for syphilis. Before the pathogen of syphilis became known to science, syphilis was named after the enemy or after the place where the contamination came from (Frith 2012): "the French pox," "the Polish sickness," "the German sickness," "the Neapolitan sickness," "the Spanish sickness," or "the Castilian sickness," and "the Canton rash" (Frith 2012). Similarly, Lobsang Tsültim, who was the first among Mongolian physicians to describe this disease,

3 During the 50th year of the Qianlong reign (1785), a military physician of the Chakhar territory wrote a letter to the higher authorities that a Chinese merchant spread the infection of syphilis to several women and passed it on to a soldier. He also asked that the merchant be sent back to China and that mercury and calcite be provided for the treatment of syphilis. 
called it the "Chinese ulcer." Lobsang chos 'phel also gave a thorough description of syphilis and its symptoms (Lobsang chos 'phel 2008, p. 313).

There were several factors that contributed to the spread of syphilis among Mongols, especially in highly populated regions (Maiskii 1921, p. 31; Hetian 1949, p. 128). One factor was a significant percentage of unmarried adults in Mongolia. While the Qing authorities supported the spread of Buddhism, a law was passed that decreed an allowance of only 40 men becoming monks in each district of Mongolia. However, the regulation was gradually broken, and the total number of monks increased rapidly (Ochir and Enkhtuvshin 2004, p. 211). By 1918, the number of monks amounted to 105,577 which is nearly half (44.5\%) of men in Khalkha Mongolia (Maiskii 1959, p. 42). By this time there were some 1600 temples and 100,000 monks in Inner Mongolia (Ochir and Enkhtuvshin 2004, p. 212). Since fully ordained monks were not allowed to marry, a considerable number of women remained unmarried. These circumstances left the possibility open for casual and extramarital sexual relations which, in turn, contributed to the spread of sexually transmitted diseases. Poor personal hygiene was also one of the main causes of the spread of infections. There was a lack of epidemiological knowledge and inadequate medical care and efforts for prevention. Furthermore, the Mongolian cultural view of sexually transmitted diseases as shameful prevented the infected persons from seeking medical care.

\subsection{Plague: Marmot Disease}

Marmot pelt was one of the Mongols' common trading products with Russia and marmot meat is considered to be a delicacy by Mongolian hunters to this day. A rapid increase in the export of marmot pelt to Russia was observed in 1906-1910 as 13 million were traded, over 400 times more than the meager 30,000 exported in 1865 (Summers 2012, pp. 119-20). The plague caused by infected marmots, contemporarily referred in Mongolian as "tarvagan takhal," posed a yearly threat to the nomads. Towards the turn of the 20th century, Western medicine had little acquaintance with bubonic plague (Summers 2012, p. 7). The yearly outbreaks of plague among marmots were not only common in Mongolia but also in Manchuria and the Transbaikal regions of Russia. In consequence, the Russian government sent medical expeditions to those regions that were infected by marmot plague, which they interpreted as a bubonic plague (Anonymous 1907). Russian reports dating from 1888 and cited by Paul Preble revealed that a plague originally came from Eastern Mongolia. Preble observed that this infectious disease did not affect domestic animals. Only marmots and humans who came into contact with infected marmots were affected (Preble 1912).

\section{Mongolian Buddhist Interpretations of Infectious Diseases}

In Tibetan and Mongolian Buddhist traditional medicine, infectious diseases are classified into three main categories: rims nad (infectious disease), dug nad (diseases related to poison) and gnyan nad (spirit-related diseases). Infectious diseases like smallpox, diarrhea, diphtheria, anthrax and flu are categorized as rims nad. The Tibetan term "dug" "toxin" or "poison," (Mong. khor) refers to illnesses caused by poisons, venomous animals, and poisonous plants. It also includes some venereal diseases transmitted through physical contact (Tib. reg $d u g$ ). Tibetan medicine also recognizes many different types of poisonous diseases, as for example, meat contaminations (Tib. sha dug). The Mongolian Buddhist author Ye shes dpal 'byor (1704-1788) included other infectious diseases in the category of "dug" illnesses. For instance, he adds rabies, which he terms "a dog poison"4 (Ye shes dpal 'byor 2007, p. 357). In contrast, he refers to the bubonic plague as a "marmot poison" (Mong. tarba ran-u qor). He also wrote about measles and flu and prescribed their treatments.

4 Written Mong. noqoi-yin qor (dog-poison"). He also here provides information on the signs of a rabid dog and a rabid wolf, the symptoms that occur after one has been bitten and infected by them, the diagnostic methods and treatments offered in different stages of the disease such as the application of bandages and drawing fluid from the bite wound by a suction device. 
Ye shes dpal 'byor describes "gnyan" (evil spirit), which in modern-day Mongolian refers to bacteria, as a red, round bug (Mong. khorkhoi) without legs. It was also said that there are seven different types, all very poisonous. Depending on the location of infection, 19 different types of the diseases are identified. For example, if the bug enters into the spinal cord, it is said to be a cause of convulsion; if it enters the throat, it causes a sore throat or diphtheria; if it enters the ear, it causes earache; and it also causes swollen glands when it reaches the glands, and so on. According to Lobsang chos "phel, these "gnyan" diseases are highly infectious to both humans and animals. He suggested a miasmatic idea that infectious agents can spread by smell.

The Method to Prepare Oil based Basam Medicine and Five Elixir Medicinal Baths by Chakhar Géshé Lobsang Tsültim contains information on preparing medicines for the treatment of infectious diseases that cause shivers (Tib. 'Dar ba nad) and syphilis, and the smallpox inoculation. Interestingly, according to the treatise, "pha yo'u sa zer ba bcag mal" is Tibetan transliteration of a Chinese expression which means 'Dar ba nad in Tibetan and describes an infection with periodic symptoms of shaking, cold and heat that shows similar symptoms to malaria. The text details the treatment and the avoidance of direct contact with the patient. If it really refers to malaria, it is quite unusual in the case of Mongolia due to its semi-arid weather conditions. Although malaria is not common in Mongolia, it could be brought over to the south part of Mongolia (recent Inner Mongolia) where the climate is different.

This was an advanced treatise for that period in the history of Mongolian medicine, as it describes not only the treatments of the mentioned infections but also the primary prevention and hygienic practices for common infectious diseases.

In the Mongolian and Tibetan traditional medical systems, some causes of infections are identified as malevolent spirits. Thus, the origin of infectious diseases, which is now known to be a specific organism, was traditionally related to certain demons-specifically to female demons who are believed to produce infectious vapor of the yellow, red, or black variety (Sangyé-Gyatso 2005a). It was also believed that maltreatment of the natural environment angers the Earth Deity and nāgas. When they are offended, they cause hardships such as illness, misfortunes and continual agitation in small children. Additionally, in Ye shes dpal 'byor's view, any improper treatment of nāgas can irritate them and cause them to spread poisonous vapor that induces infectious diseases such as leprosy (Ye shes dpal 'byor 1998, p. 249).

\section{Treatment of Infectious Diseases in Tibetan-Mongolian Buddhist Medicine}

According to the Tibetan and Mongolian medical system of classifying diseases, there are 101 disorders that are considered treatable through religious practices. Among them are disorders caused by demons, the Earth Deity, and nāgas. For the treatment of diseases inflicted by malevolent spirits, two general types of rituals are prescribed: gentle and fierce rituals. Gentle religious healing practices are to be performed first. They include the water and torma $a^{5}$ offerings to spirits with the aim of appeasing them. With regard to this, Ye shes dpal 'byor (1704-1788) wrote: "To heal disorders caused by spirits, make torma offerings and chant the mantra of the Five Guardians" (Ye shes dpal 'byor 1998, p. 384-86). In the case that a gentle ritual has been ineffective, a stronger ritual, accompanied by the chanting of a "fierce mantra" and fire offering ritual, was to be performed (Sangyé-Gyatso 2005b, p. 1089). These rituals are often performed in order to clear away malevolent spirits and to relieve the patient from suffering. The traditional belief of Mongolians has been that fire can purify the impure objects and expel demons. This practice of gentle and fierce treatments continues to be in use today in some regions of Mongolia.

Owing to the greater understanding of the epidemiology of infectious diseases and due to the borrowing of medical practices from medical systems of other countries, new therapeutic methods eventually developed in Mongolia. In order to effectively deal with new infectious diseases such as

5 Tor $m a$ is a ritual, sacrificial cake offering. 
syphilis, Mongolian physicians devised new methods. Chinese traditional medicine became a source for adopting effective management by Mongolian Buddhist physicians. For Chinese medicinal names for the treatment of syphilis see Figure 1.

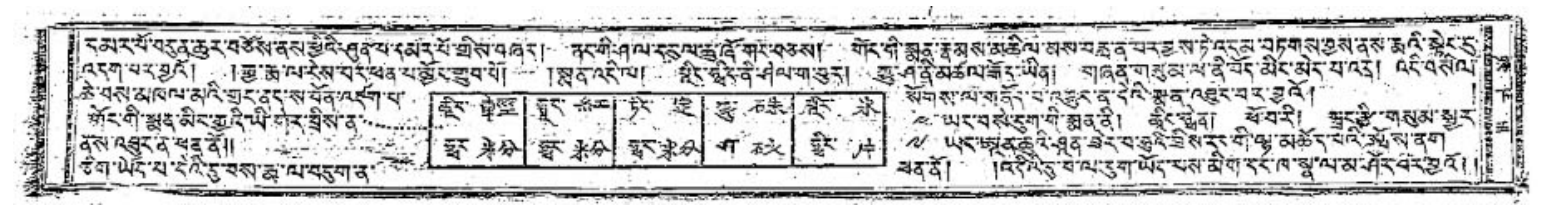

Figure 1. The Method to Prepare Oil based Basam Medicine and Five Elixir Medicinal Baths by Chakhar Géshé Lobsang Tsültim (1740-1810).

According to Chakhar Géshé Lobsang Tsültim's Method for Preparing Oil-based Basam Medicine and Five Elixir Medicinal Baths, 輕粉 (qīng fẽn), or calomel or mercury chloride; 紅粉 (hóng fẽn), or

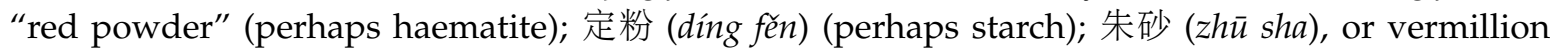
or cinnabar; mercury sulphide, and 冰片 (bing piàn), or borneol $(\mathrm{C} 10 \mathrm{H} 18 \mathrm{O})$, are to be used for the treatment of syphilis.

Mercury was, in general, the only therapeutic substance for the treatment of syphilis until the appearance of arsphenamine treatment, known as Salvarsan, in 1910. Ointment made of mercury was used as the main medicine until ingestion of mercury chloride was introduced by Austrian surgeon Gerhard van Swieten (1700-1772). This remained in use until the beginning of the 20th century (Garrison 1929; Singer and Underwood 1962), despite the fact that many patients died of mercury poisoning. In 1894, Guido Bacelli developed an injected form of mercury chloride, creating a more efficient method of its use internally (Frith 2012). The first use of penicillin in 1943 was a ground breaking moment in the treatment of the disease as it replaced the prior treatments.

In his works mentioned above, Chakhar Géshé describes a number of mercury compounds, such as mercury chloride, cinnabar (mercury sulphide), hematite, and camphor for the treatment of syphilis. It is worth pointing out that in traditional Mongolian Buddhist medicine, sulfur was used alongside the mercury compounds for the purpose of detoxifying the mercury. Chakhar Géshé pointed out negative side effects of the application of mercury (one of which is the cold kidney disease) and he prescribed treatments that would alleviate the negative side effects. The aforementioned Chinese medicinal ingredients for the treatment of syphilis which were suggested by Chakhar Géshé were also cited by Lobsang chos 'phel, who additionally recommended medicinal compounds made from different medicinal herbs and animal products. These included ingredients such as goat meat and blood, crocodile blood, elephant bile stone, bear bile, rhinoceros horn, musk, saiga antelope horn and also human milk (Lobsang chos 'phel 2008, p. 227).

Additionally, in Ye shes dpal 'byor's writings on sexually transmitted diseases we find short sections dealing with symptoms related to a genital inflammation in humans, such as a local irritation, a discharge from the genitals and the change of color in the genitals. According to Ye shes dpal 'byor, one of the main causes of these may be excessive sexual activity. For the treatment of a genital inflammation, he prescribed a medicine called "khyung 5," mercury, and black alum, and recommended abstinence from sexual intercourse during the period of treatment. Furthermore, for the treatment of infected women, he prescribed a topical application to the vagina. Certain antimicrobial ingredients, including black alum mixed with oil and honey, are to be poured into an animal pericardium and a straw inserted in it, by means of which the medicine is pumped into the vagina (Ye shes dpal 'byor 1998, pp. 198-199, and Ye shes dpal 'byor 2007, p. 324). Since orally ingested medicine for the treatment of infections was not always effective, this thick, oil-based preparation proved to be more operational due to its localized application. The method of delivering medicine through vaginal routes had many advantages including the avoidance of digestive enzymes through the ingestion of medicine. Direct application of medicine on the site of infection had minor negative side effects on the body. 
According to Ye shes dpal 'byor's advice, mercury is to be used for the treatment of a variety of infectious diseases. For the treatment of swollen and painful testicles he prescribed adding mercury to certain medicines (Ye shes dpal 'byor 1998, p. 324). In the treatment of smallpox, one is to use scabs from a smallpox infected person and goat blood (Ye shes dpal 'byor 2007, p. 291). He also suggested the usage of a diagnostic technique for the identification of smallpox, differentiating it from other diseases with similar visible symptoms. For the prevention of the formation of scars caused by the disease, one was to use goat fat. Furthermore, to prevent smallpox infection he recommended the use of products made of animal parts as well as certain Chinese medical treatments (Ye shes dpal 'byor 1998, p. 145).

Ye shes dpal 'byor claimed that a pathogen from a marmot infected by plague can be transferred to a person who eats the meat of a hibernating marmot (Ye shes dpal 'byor 2007, p. 359). In addition, in Lobsang chos 'phel's view, the marmot disease can be transmitted only through eating the meat of an infected marmot (Lobsang chos 'phel 2008, p. 224). Both authors also prescribe the ingestion of vodka infused with garlic before breakfast every morning for the prevention of infection from marmots. For the marmot disease, in his Rašiyan- $u$ dusul (Drop of Medicinal Elixir), Ye she dpal 'byor suggested therapeutic methods that involved drinking vodka in the early morning and bathing in the cold water of a lake or river until the body begins to shiver, after which one ingests the nine "black medicines" 6 (Ye shes dpal 'byor 2007, pp. 451-52).

\section{The Prevention and Prophylactics of Infectious Diseases}

The main measures used against the spread of infectious diseases were quarantine of infected persons and disposal of the infected materials and corpses. A German traveler in the Altai region of Russia, Peter Simon Pallas (1741-1811), observed that Mongols used to isolate an infected person and deliver food to the patient from the upwind direction (Pallas 1980, p. 158). However, investigation of different sources reveals that the prevention of infectious diseases among Mongols was not limited to quarantine, as there were other measures mentioned in Mongolian legal texts and in the internal regulations of individual monasteries. Scholars also emphasized the use of preventive medicines and personal hygiene.

The Khalkha Regulations (Khalkha Juram), created by a group of Mongolian nobles during their assembly in 1709, was the main legal document that regulated the social life of Khalkha Mongols from 1709 to 1911 (Ochir and Enkhtuvshin 2004, p. 298). A statute related to the regulation of human life and health is mentioned under article 8 of the Khalkha Regulations. According to this statute, those who concealed their infectious disease and spread it to others were punishable with a fine in livestock (Jalan-aajav 1995, p. 37). There are also several documents kept in the Mongolian National Archives that were issued in relation to the transmission of syphilis from one person to others (Dolgor and Nyamdorj 1960). The document titled "The Order to Tserengpel, the Head of a Horse Relay Dem Belgekh" mentions the case of a woman who was infected with syphilis after being raped. It was decided that the cost of her treatment be paid by her rapist. ${ }^{7}$ Another report from 1808, issued by certain authoritative figure of "Sair $\mathrm{Us}^{\text {" }}$ states the same penalty for the person who spread syphilis to a family, which eventually led to divorce. ${ }^{9}$

Syphilis was spread not only among laypeople but also among the monastic community. Therefore, monasteries made a strong appeal to monks to follow the precept of sexual abstinence in order to curb the spread of syphilis. Some monasteries also made their own internal regulations for preventing

6 Lobsang chos 'phel identified the nine black medicines as consisting of black frankincense, black species of aconite, black hellebore, asafoetida, musk, sulphur, realgar, yellow orpiment, oxytropis, thermopsis lanceolate, child urine and feces, and the residue of a burnt goat horn.

7 Mongolian National Archives, Manchu section, \# 6-32-2, the fourth year of Jiaqing Emperor Reign (1800).

8 The name of a place.

9 Mongolian National Archives, Manchu section, \# 6-32-1, the 12th year of Jiaqing Emperor Reign (1808). 
the spread of this infectious disease. For example, in 1896 one regulation stipulated that women in Dashdandarling aimag $^{10}$ are permitted to visit the temple only on certain days under police supervision, in order to prevent the spread of the "Chinese ulcer" among monks. ${ }^{11}$ If someone violated this regulation, the monastery's disciplinarian (Mong. gesgüi, Tib. dge bskos) and the person who violated it were to be penalized with a substantial fine.

Smallpox inoculation was the best example of preventive medicine of that time. Peter C Perdue was wrong in arguing that Mongols never adopted inoculation against smallpox (Perdue 2005, p. 47). However, quarantine was one of many options, as seen from several medical treatises that mention other preventive methods against the infection. For instance, in the works of Mongolian Buddhist scholars, the use of scabs from the person infected with smallpox is mentioned as a form of inoculation. Chakhar Géshé Lobsang Tsültim was the first among Mongolian Buddhist scholars to compose an independent work on smallpox inoculation through the respiratory tract, using scab of the infected person. The Method to Prepare Oil based Basam Medicine and Five Elixir Medicinal Baths contains important information on the prevention of smallpox and on matters of hygiene. According to this work, the preparation procedure and the inoculation technique for smallpox is harmonized with traditional medical theory and integrated into the Mongolian nomadic lifestyle and Buddhist rituals (Norov et al. 2019). It is recommended that the inoculated person stays calm, warm, avoids noise from livestock, loud worshipping, negative mental states, and abstains from eating camel meat, ${ }^{12}$ since these are believed to aggravate the bodily wind element. Additionally, for the prevention of an uncontrolled spread of the disease, good hygiene must be well maintained. This was done by avoiding trade goods (such as clothes and bedding) as well as shaking and dusting off of one's clothes outside the home, especially when the external conditions are windy. As the treatise states, after the inoculation procedure activities and food which increase the wind element need to be avoided. Additionally, reciting the mantras thamo and lomogyonma is encouraged as this clears away demons and infectious diseases (Lobsang-Tsültim 1785). This treatise describes some methods of quarantine as well as the prevention of super-infection, highlighting various sanitary methods.

The idea of the prevention of an infectious disease presented by Ye shes dpal 'byor can be considered as the most advanced of his time. In his view, the avoidance of infection is of two types: the physician's self-protection and his protection of others. For his self-protection, the physician is advised to chew a garlic clove and rub it around the nasal area, which would protect him for the duration of a day. In protecting others, he should rub certain parts of the body with a medical compound made of a mixture of garlic, sulfur, and musk, or he should apply this mixture around the patient's neck so that the patient may regularly inhale it (Ye shes dpal 'byor 1998, p. 140). In contemporary medicine, garlic continues to be used to defend the body from pathogens in certain places.

\section{Discussion}

The spread of infectious disease had a profound socio-political impact on Mongolia during the 17th to 20th centuries. Various sources demonstrate that the population decline in Mongolian territories from the 17th to the early 20th centuries was due to disease epidemics. Similar to the case of Native American tribes, a high death rate among adults in Mongolia resulted from the lack of immunity to the mentioned infectious diseases (Perdue 2005). Mongolia lost many of its most capable people and the leaders of anti-Qing forces as a consequence of this. Therefore, the spread of infectious diseases among Mongols was undoubtedly one of the reasons for the weakening of the Mongolian capacity for

10 Niislel Khüree, the main monastic center of Mongolia prior to 1921, also known as Urga, was divided into two sections: Baruun Khüree and Züün Khüree. The area around the Gandantegchinleng monastery was called Baruun Khüree, and the central part of the capital was called Züün Khüree. This was also a place where monks resided. Züün Khüree was divided into 30 districts (aimag), including, the Dashdandarling aimag. Every monk in the capital city belonged to an aimag of Züün Khüree.

11 Mongolian National Archives, Manchu section, \# 7-33-26, the 21st year of the Guangxu Emperor's reign (1896).

12 In traditional Mongolian medicine, camel meat is considered to have a cold quality, which induces the wind element. 
self-defense. At the beginning of the 20th century the conditions of disease, poor life expectancy and low birth rate were very bad and some sources such as Haslund (1896-1948) claimed that the Mongols, once having been great people, were heading to ruin (Braae 2017). In response to this, Mongolian Buddhist scholars continuously sought new treatments and preventative techniques against the threat.

The description of marmot disease and rabies were not mentioned in the fundamental text of the Four Medical Tantras and its supplementary books. These kinds of infections very frequently affected nomads and are considered to be linked to their lifestyle and diet. Ye shes dpal 'byor further acknowledged that several different plagues ${ }^{13}$ can also be transmitted from marmots and from rabid dogs and wolves. With this, he explained that the spread of the infections takes place through contact with an infected animal.

Another important practice of Ye shes dpal 'byor is the treatment for local inflammation of female genitalia. The administration of medicines through the vaginal route was uncommon in the Tibetan Buddhist medical system until it was mentioned by him. Additionally, Mongolians had some experience administering medicines by different routes. According to Derek Doyle it appears that a rectal route for administering a fluid enema was first used by Mongolian physicians who utilized the horn and the bladder of animals in their treatments (Doyle 2005).

Until the beginning of the 20th century humanity could not find effective medicines for syphilis except for treatment with mercury. This also meant that a considerable number of people lost their lives as a result of its side effects, as opposed to dying because of the syphilis. The treatment was the only one for the disease at the time. However, medicines which involve detoxified mercury are still in use in recent Mongolian traditional medicine for the treatment of some skin pathologies. When syphilis first began to spread Tibetan and Mongolian medical knowledge did not include an understanding of how to cure the disease. Chinese medicine became a source for Mongolian Buddhist physicians looking for effective management of the disease. Undoubtedly, the use of the mercury treatment in Western medicine was inseparable from its pathogen and the spread of the disease to Asia was closely followed by its treatment. A careful investigation of the treatment of syphilis reveals that it did not develop noticeably over the period; however, Lobsang chos 'phel gave more precise details about the symptoms of the infection.

Smallpox inoculation is the one of the best examples of the globalization of medical knowledge. It was widely used around the world until the development of the smallpox vaccine by Edward Jenner (1749-1823). The procedure was likewise practiced in Mongolia, with Chakhar Géshé Lobsang Tsültim providing an important stimulation for the use of the technique. His treatise became the most important and widely used manual for medical practitioners during the time. His disciple Lobsang-Samrübnima (18th-19th century) stated the importance of this manual "which saved numerous lives" (Lobsang-Samrübnima 2008).

Additionally, the Mongolian scholars emphasized the importance of hygiene, but this was a burning problem among Mongols. Several travelers such as Gilmore claimed that nearly all the diseases among the Mongols were triggered by their poor hygiene (Gilmore 1908).

Legal measures regarding the prevention of infectious diseases were instituted mainly by local administrators for their local communities. There was not much in the way of large scale management policies against the epidemics, except for the article on infectious disease in the Khalkha Regulations, which would address the problem for the entire population.

After adopting the Tibetan Buddhist medical theory and practice, Mongolian traditional medicine developed systematically and was continually enriched by Mongolian Buddhist scholars. Mongolian scholars contributed to Mongolian Buddhist medicine with their own ideas and practices, including the areas of preventive and therapeutic medicine for infectious diseases. They did so by integrating the

13 One of these is a marmot disease. 
pre-Buddhist Mongolian medical practices that were absent in Tibetan medical treatises with Chinese medicine and with the acquired Tibetan medical knowledge.

Statements in the above discussed Mongolian scholars' medical works, about the mercury treatment for syphilis and smallpox inoculation indicates that the scholars adopted the most contemporary medical knowledge at that critical period. Certainly, medical information was constantly exchanged with coexisting medical traditions such as the Tibetan and Chinese. In our study case of infectious disease management, it is evident that Mongolian medical scholars made some significant contribution to medical data syncretism in traditional medicine.

Funding: This research received no external funding.

Conflicts of Interest: The author declares no conflict of interest.

\section{References}

Altangerel. 1967. Mongol zokhiolchdyn tövdöör bichsen büteel. 1 devter [Tibetan works written by Mongolian scholars. 1st volume]. Ulaanbaatar: Printing of Mongolian Academy of Sciences.

Andrews, Roy Chapman. 1921. Across Mongolian Plains. New York: D. Appleton and Company.

Anonymous. 1907. Plague and the "Tarbagan" disease in Mongolia. The Lancet 170: 1630. [CrossRef]

Atwood, Christopher Pratt. 2004. Encyclopedia of Mongolia and the Mongol Empire. New York: Facts On File, Inc. Baigalma, Ürjin. 2006. Mongolyn Ulamjlalt Anagaakh Ukhaany Onoshlogo. Ulaanbaatar: Khutaibilg Töv.

Bareja-Starzyńska, Agata. 2018. Jebtsundamba Khutugtus of Mongolia. In Religion. Oxford: University of Oxford.

Bawden, C. R. 1968. The Modern History of Mongolia. New York: Praeger, p. 146.

Bayarsaikhan. 2004. Jinkhene Dagaj Yavakh Khuuly Dürem: 1913-1918. Edited and transliterated into Cyrillic by Bayarsaikhan. Ulaanbaatar: University Of Mongolia, p. 1.

Bira. 1960. Tövdöör bichsen Mongolchuudyn tüükhyn zokhiol [History books by Mongolians in the Tibetan language]. The Study of History 3: 17-34.

Braae, Christel. 2017. Among Herders of Inner Mongolia: The Haslund-Christensen Collection at the National Museum of Denmark. Aarhus: Aarhus University Press, p. 502.

Bulag, Uradyn. 2010. Collaborative Nationalism: The Politics of Friendship on China's Mongolian Frontier. Plymouth: Rowman \& Littelfield Publishers, Ltd., p. 207.

Cariceo, Mercedes C. 1994. Maternal Mortality in Mongolia: Cultural and Institutional Factors. Master's dissertation, York University, Toronto, ON, Canada.

Chang, Chia-Feng. 2002. Disease and Its Impact on Politics, Diplomacy, and the Military: The Case of Smallpox and the Manchus (1613-1795). Journal of the History of Medicine and Allied Sciences 57: 177-97. [CrossRef] [PubMed]

Cosmo, Nicola Di. 2012. From Alliance to Tutelage: A Historical Analysis of Manchu-Mongol Relations before the Qing Conquest. Frontiers of History in China 7: 175-97.

Damdinsuren, Tsend. 1958. Erdeniin san Subashid. Tsakhar gevsh Luvsanchultemiin orchuulga ba tailbar [A Treasury of Aphoristic Jewels. Translation and explanation by Chakhar Géshé Lobsang Tsültim]. Ulaanbaatar: State Printing.

Damdinsuren, Tsend. 1975. Tsakhar gevshiin üil ajillagaany zarim ontslogyn tukhai [Some features of Chakhar Géshés' activity]. Mongolian Study 2: 28-34.

De Jong, Jan Willem. 1967. Sum-pa mkhan-po (1704-1788) and His Works. Harvard Journal of Asiatic Studies 27: 208-16. [CrossRef]

Dolgor, Ch., and Tse Nyamdorj. 1960. Mongol orond tembüü delgersen zarim neg barimt [Some facts on syphilis spread in Mongolia]. Eruul Mend 3: 52-54.

Doyle, Derek. 2005. Per rectum: A history of enemata. The Journal of the Royal College of Physicians of Edinburgh 35: 367-70. [PubMed]

Elverskog, Johan. 2006. Our Great Qing: The Mongols, Buddhism and the State in Late Imperial China. Honolulu: University of Hawai'i Press.

Frith, John. 2012. Syphilis-Its early history and Treatment until Penicillin and the Debate on its Origins. Journal of Military and Veterans' Health 20: 49-58.

Garrison, Fielding Hudson. 1929. An Introduction to the History of Medicine. Philadelphia: WB Saunders Co.

Gilmore, Rev James. 1908. Among the Mongols. London: Religious Tract Society, p. 186. 
Hanung, Kim. 2014. Sum-pa Ye-shes-dpal-'byor and the Civil War of Eighteenth Century Tibet: A Preliminary Essay on Ye-shes-dpal-'byor's Many Roles in Tibetan Civilization. Journal of Research Institute 51: 165-82.

Hays. 2005. Epimedics and Pandemics Their Impact on Human History. Santa Barbara: ABC-CLIO Inc., p. 116.

Hetian, Ma. 1949. Chinese Agent in Mongolia. Translated by John De Francis. Baltimore: Johns Hopkins Press.

Hopkins, Donald. 2002. The Greatest Killer. Chicago: University of Chicago Press, p. 119.

Jalan-aajav. 1995. Khalkha Juram. Edited by Jalan-aajav. Ulaanbaatar: Mongol Ulsiin Khuuli Züin Yam.

Khaidav. 1975. Dorno dakhinii anagaakh uhaanii sudar bichgiin toim [Review of Eastern Medical Treatises]. Ulaanbaatar: Mongolian Academy of Science.

Lobsang chos 'phel. 2008. gces bsdus snying nor. Lhasa: People's Press Bureau of Tibet.

Lobsang-Samrübnima. 2008. Getülgegči degedü blam-a adiltġal ügei ačitu Bogda Sumadi Šila Širi Badr-a-yin gegein-ü eirünghei-yin jokhiol namtar-i tobči-yin tedủi egülegsen süsüg-ün linqu-a-yi müsiyelgegči naran-u gerel degedü mör-i geyigülün üildügči khemegdekhü orošiba. Translated from Tibetan by Jurmeddanzan. Khokhot: People's Press Bureau of Inner Mongolia.

Lobsang-Tsültim. 1785. 'Ba' sam sman mar dang 'dud rtsi lnga lum sogs bya tshul bzhugs so. Xylographic Print, Folios. Chakhar: Tsagaan Uulyn Süm, pp. 1-8.

Maiskii. 1921. Sovremennaya Mongoliya. Irkutsk: 1-ya gosudarstvennya tipografiya.

Maiskii. 1959. Mongoliya Nakanune Revolyutsii. Moscow: Izdatelsvo vostochnoi literatury.

Norov, Batsaikhan, Vesna A. Wallace, and Batchimeg Usukhbayar. 2019. The Smallpox Inoculation by Chahar Géshé Lobsang Tsültim. In Buddhism \& Medicine: An Anthology: Modern and Contemporary Voices. Edited by C. Pierce Salguero. New York: Columbia University Press, in press.

Ochi. 1996. Chahar Géshé Lobsang Tsültim. Khailaar: Inner Mongolia National Printing.

Ochir, A., and B. Enkhtuvshin. 2004. Mongol Ulsiin Tuukh. Ulaanbaatar: Admon press.

Ochirbat. 1974. Khuuchin Mongold tembüü uvchin delgersen tukhai. Mongoliin Anagaakh Ukhaan 2: 18.

Pallas, Peter Simon. 1980. Sammlungen historischer Nachrichten über die mongolischen Völkerschaften, 2 vols. St. Petersburg: Gedruckt bey der Kayserlichen Akademie der Wissenschaften, 1776-1801. p. 158.

Parker. 1907. Smallpox and inoculation in China. British Medical Journal 1: 88-90.

Perdue, Peter. 2005. China Marches West: The Qing Conquest of Central Eurasia. Cambridge: Harvard University Press.

Pozdneyev, Aleksei Matveevich. 1971. Mongolia and the Mongols. Uralic and Altaic Series. Edited by John R. Krueger. Translated from the Russian by John Roger Show and Dale Plank. Bloomington: Indiana University Press, p. 61.

Pozdneyev, Aleksei Matveevich. 1980. Sketches of Life of Buddhist Monasteries and Buddhist Clergy in Mongolia. Seattle: University of Washington.

Preble, Paul. 1912. The Tarbagan (Arctomys bobac) and Plague. Public Health Reports (1896-1970) 27: 31-39. [CrossRef]

Rupen, Robert A. 1964. Mongols of the Twentieth Century. Uralic and Altaic Series 37: 349.

Sangyé-Gyatso. 2005a. Man ngag lhan thabs dan lde mig. Pec in: mi rigs dpe skrun khang.

Sangyé-Gyatso. 2005b. rgyud bzhi'I gsal byed baiDUrya sngon po. Lhasa: People's Press Bureau of Tibet, vol. 2, p. 1089.

Serruys, Henry. 1980. Smallpox in Mongolia during the Ming and Ching dynasties. Zentralasiatische Studien 14: 41-43. [PubMed]

Sharav, Bold. 2006. Mongolyn Ulamjlalt Agagaakh Ukhaany Tü̈̈kh [Hystory of Mongolian Traditional Medicine]. Ulaanbaatar: Admon press.

Singer, Charles, and Edgar Ashworth Underwood. 1962. A Short History of Medicine. London: Oxford University Press.

Sinor, Denis. 1997. Inner Asia: History, Civilization Languages. The Hague: Mouton \& Co., p. 29.

Solomon, Susan Gross. 1993. The Soviet-German Syphilis Expedition to Buriat Mongolia, 1928: Scientific Research on National Minorities. Slavic Review 52: 204-32. [CrossRef]

Sühe. 2002. Erqim teguburi. In Encyclopaedia of Mongolology: Medicine. Edited by Oyunchimeg. Khuh hot: People's Press Bureau of Inner Mongolia.

Summers, William. 2012. The Great Manchurian Plague of 1910-1911: The Geopolitics of an Epidemic Disease. New Haven and London: Yale University Press, pp. 119-20. 
Ye shes dpal 'byor. 1998. Durben Rašiyan. Khuh hot: People's Press Bureau of Inner Mongolia. Ye shes dpal 'byor. 2007. Sum pa'i sman yig phyogs bsgrigs. Lhasa: People's Press Bureau of Tibet.

(C) 2019 by the author. Licensee MDPI, Basel, Switzerland. This article is an open access article distributed under the terms and conditions of the Creative Commons Attribution (CC BY) license (http:/ / creativecommons.org/licenses/by/4.0/). 